\title{
A field investigation of phreatophyte-induced fluctuations in the water table
}

\author{
James J. Butler Jr., ${ }^{1}$ Gerard J. Kluitenberg, ${ }^{2}$ Donald O. Whittemore, ${ }^{1}$ \\ Steven P. Loheide II, ${ }^{3,4}$ Wei Jin, ${ }^{2}$ Mark A. Billinger, ${ }^{5}$ and Xiaoyong Zhan ${ }^{1,6}$ \\ Received 30 September 2005; revised 25 May 2006; accepted 12 September 2006; published 7 February 2007.
}

[1] Hydrographs from shallow wells in vegetated riparian zones frequently display a distinctive pattern of diurnal water table fluctuations produced by variations in plant water use. A multisite investigation assessed the major controls on these fluctuations and the ecohydrologic insights that can be gleaned from them. Spatial and temporal variations in the amplitude of the fluctuations are primarily a function of variations in (1) the meteorological drivers of plant water use, (2) vegetation density, type, and vitality, and (3) the specific yield of sediments in the vicinity of the water table. Past hydrologic conditions experienced by the riparian zone vegetation, either in previous years or earlier within the same growing season, are also an important control. Diurnal water table fluctuations can be considered a diagnostic indicator of groundwater consumption by phreatophytes at most sites, so the information embedded within these fluctuations should be more widely exploited in ecohydrologic studies.

Citation: Butler, J. J. Jr., G. J. Kluitenberg, D. O. Whittemore, S. P. Loheide II, W. Jin, M. A. Billinger, and X. Zhan (2007), A field investigation of phreatophyte-induced fluctuations in the water table, Water Resour. Res., 43, W02404, doi:10.1029/2005WR004627.

\section{Introduction}

[2] Water level records from wells screened in shallow aquifers often display fluctuations of varying frequencies and magnitudes [Kruseman and de Ridder, 1990; Healy and Cook, 2002]. Common mechanisms responsible for shortterm (hours to days) fluctuations include cyclical pumping of nearby wells and changes in stream stage or barometric pressure. Longer-term (months to years) fluctuations are commonly attributed to variations in climate and anthropogenic water use. Hydrographs from shallow wells in riparian zones with phreatophytes (plants that tap the saturated zone for their water supply [Robinson, 1958]) frequently display a distinctive pattern of diurnal fluctuations (Figure 1). Although first linked to variations in plant water use early in the last century [Meinzer, 1927], these diurnal water table fluctuations have received relatively little attention in the literature beyond the pioneering work of White [1932], Gatewood et al. [1950], and Robinson [1958] and the recent work of Loheide et al. [2005] and Engel et al. [2005]. In particular, relatively little attention has been given to assessing the major controls on these fluctuations and

\footnotetext{
${ }^{1}$ Kansas Geological Survey, University of Kansas, Lawrence, Kansas, USA.

${ }^{2}$ Department of Agronomy, Throckmorton Plant Sciences Center, Kansas State University, Manhattan, Kansas, USA.

${ }^{3}$ Department of Geological and Environmental Sciences, Stanford University, Stanford, California, USA.

${ }^{4}$ Now at Department of Civil and Environmental Engineering, University of Wisconsin-Madison, Madison, Wisconsin, USA.

${ }^{5}$ Division of Water Resources, Kansas Department of Agriculture, Stockton, Kansas, USA.

${ }^{6}$ Now at MACTEC Engineering and Consulting, Inc., Oakland, California, USA.
}

Copyright 2007 by the American Geophysical Union. 0043-1397/07/2005WR004627 how best to exploit the information embedded in water level records from shallow wells in vegetated riparian zones. A better understanding of these fluctuations should lead to improved estimates of hydrologic budgets of shallow aquifers and riparian zones, a critical issue for water resources management in arid and semiarid regions [e.g., Goodrich et al., 2000; National Research Council, 2002], as well as enhanced insights into topics ranging from the impact of afforestation [e.g., Engel et al., 2005] to the efficacy of phytoremediation [e.g., Clinton et al., 2004].

[3] The primary objective of this paper is to present results from a multisite investigation directed at clarifying the major controls on phreatophyte-induced fluctuations in the water table and demonstrating the ecohydrologic insights that can be gleaned from these fluctuations. The paper begins with an overview of the four field sites used in this work. The relationship between water table fluctuations and various meteorologic, ecologic, and hydrologic factors is examined using data sets from these four sites. Water level data from the most extensively studied site are then used to demonstrate one approach for estimating the rate of groundwater consumption by phreatophytes and to assess the magnitude of that consumption relative to a highcapacity pumping well. The paper concludes with a discussion of how phreatophyte-induced fluctuations in the water table can be utilized to better understand hydrologic budgets of shallow stream-aquifer systems impacted by plant water use.

\section{Overview of Field Sites}

[4] The primary field site used in this work, the Larned Research Site (LRS, Figure 2), was established to investigate riparian zone processes in an ecohydrologic setting common to the narrow riparian corridors characteristic of 


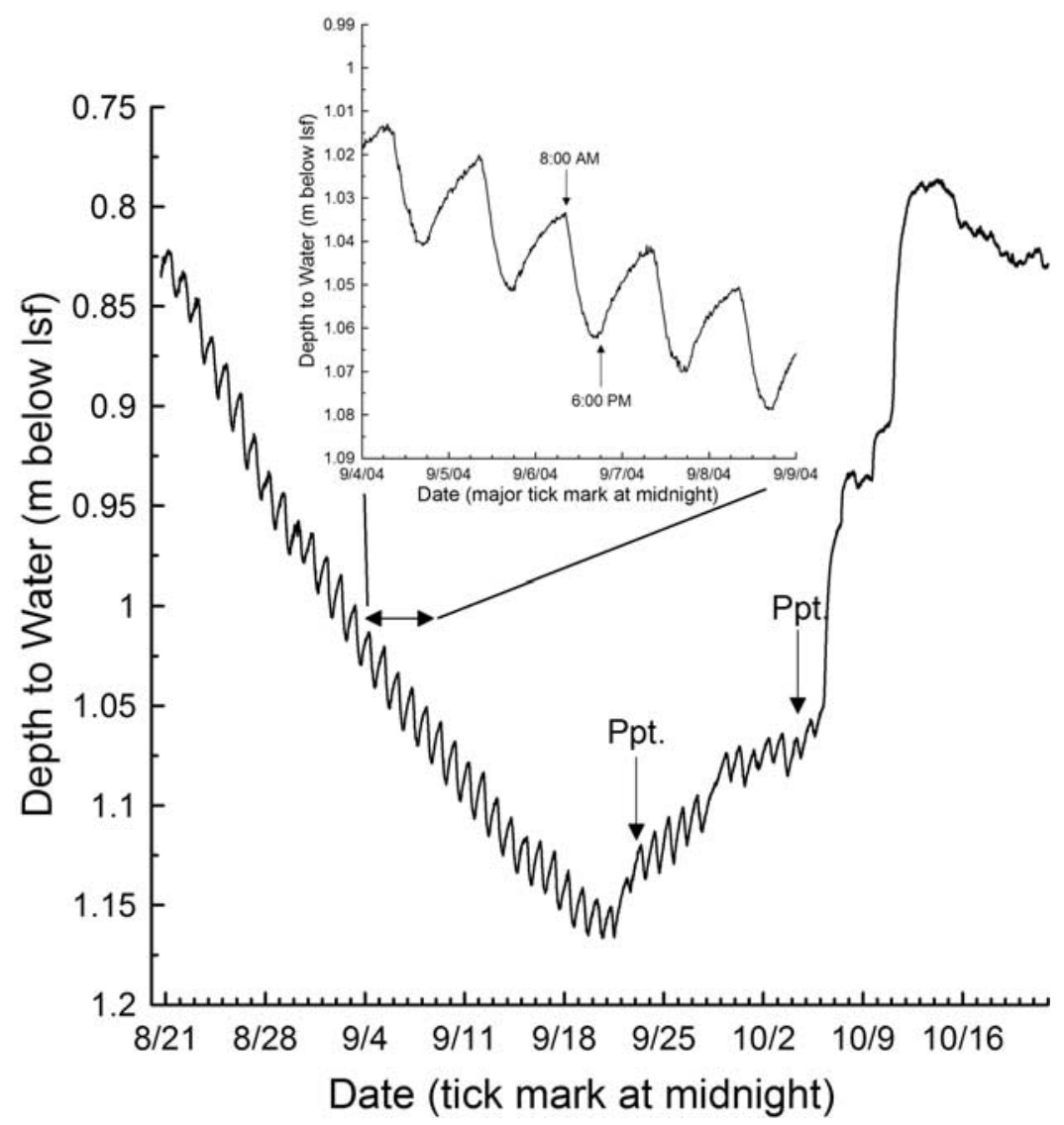

Figure 1. Depth to water from land surface (lsf) recorded at a well (Ash22) screened across the water table in the riparian zone of the Cimarron River near Ashland, Kansas. Period of record is from 20 August to 22 October 2004. Inset is expanded view of 5 days from the record (tick marks spaced every 6 hours). Rises in the water table after 21 September are primarily due to rises in the stage of the Cimarron River produced by seasonal decreases in upstream irrigation pumping and plant water use and by upstream precipitation (only the two precipitation events marked (Ppt.) occurred at the site during this period, and neither exceeded a total of $0.01 \mathrm{~m}$; first frost did not occur at site until 3 November). Well is located in a stand of large, healthy salt cedar (Tamarix spp.); Butler et al. [2005] provide details of well site and photograph of vegetation.

the High Plains region of the United States. The site, located adjacent to a U.S. Geological Survey stream-gauging station on the Arkansas River near Larned, Kansas, overlies an unconfined, coarse-sand and gravel aquifer that is in direct hydraulic connection with the intermittently flowing river [Butler et al., 2004]. The phreatophyte community at the LRS consists primarily of cottonwood (Populus spp.) with lesser amounts of mulberry (Morus spp.) and willow (Salix spp.), a mix found in many watersheds in central Kansas [Eddy, 1995; Kansas Department of Agriculture, 2002] and representative of the native riparian zone vegetation over much of the High Plains region [West and Ruark, 2004]. Ten wells are screened across the water table at various locations within and outside of the riparian zone. Each well has an integrated pressure-transducer and data logger unit submerged in the water column (30 psi absolute or gauge pressure miniTroll, In-Situ, Inc.); pressure readings are taken every 15 min and checked periodically with manual measurements (biweekly during the summer months and bimonthly otherwise). Absolute pressure sensors are used instead of gauge pressure sensors in the lower-elevation wells near the river channel to prevent sensor damage (via water movement down the vent tube of a gauge pressure sensor) when a well is overtopped during high river stages. Atmospheric pressure is recorded with on-site barometers (baroTroll, In-Situ, Inc.) to allow computation of the water table position from absolute pressure data. Moisture content in the vadose zone is monitored biweekly during the summer months using a neutron probe [Stephens, 1996] in eight access tubes located within the riparian zone. Meteorological data (air temperature, precipitation, relative humidity, global irradiance [direct and diffuse solar irradiance], and wind speed and direction) are collected every $15 \mathrm{~min}$ at a weather station (Hobo Weather Station, Onset Computing Corp.) in a pasture adjacent to the riparian zone. Sap flow data (three to four days per tree) were collected on a biweekly basis during the summer months of 2003 and 2004 using the heat pulse velocity method [Cohen et al., 1981; Schaeffer et al., 2000; Sala et al., 2001; Hultine et al., 2003] with a modified parameter estimation approach. Three trees were monitored each measurement period with two-needle sap flow sensors (Model SF18, Thermal Logic (now East 30 Sensors)). Thermocouples in the downstream needle were used to monitor temperature for 120 seconds following heating (8-s duration) 


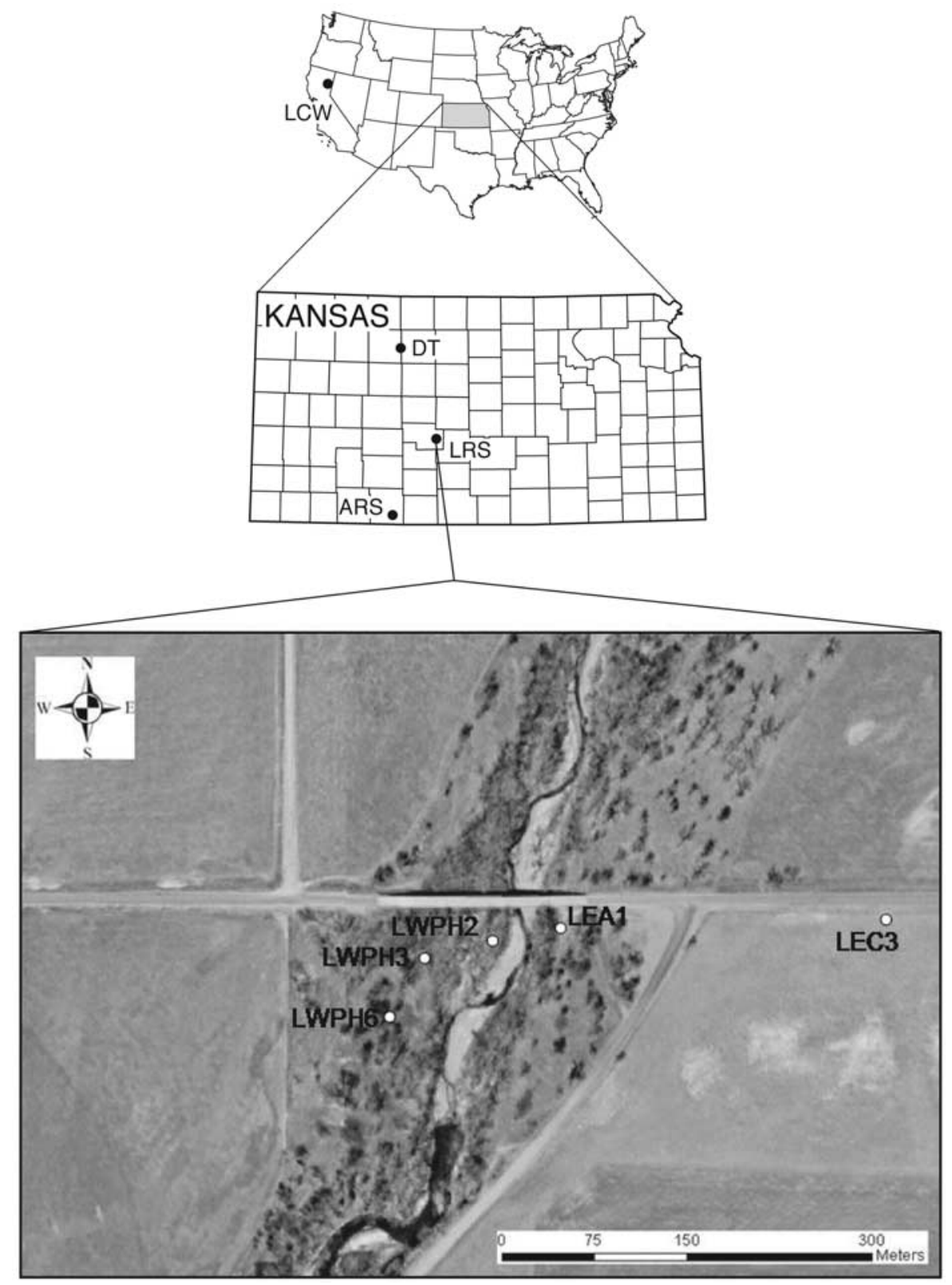

Figure 2. Location map of the primary and three auxiliary sites used in this work (ARS, Ashland Research Site; DT, Damar Transect; LCW, Last Chance Watershed; LRS, Larned Research Site (primary field area)). Aerial photo (2000) of LRS only shows wells discussed in paper; river is flowing (NNE direction) at time of photo; note water ponded behind beaver dam in lower portion of photo.

at depths of 5, 17.5, and $22.5 \mathrm{~mm}$ into the xylem. Estimates of sap velocity and xylem thermal properties were obtained by fitting (least squares optimization) equation (4) of Kluitenberg and Ham [2004] to measured temperature-time curves. The model of Kluitenberg and Ham [2004] differs from that traditionally used in the heat pulse velocity method in that it explicitly accounts for the finite duration of the heat input.

[5] Data from three additional sites (henceforth, auxiliary sites) will be used to illustrate points that are difficult to discern from the LRS data. The three auxiliary sites are the Ashland Research Site (ARS, Figure 2) located along the Cimarron River in southwest Kansas near the border with Oklahoma, the Damar Transect (DT, Figure 2) located along the South Fork of the Solomon River in north central Kansas, and the Last Chance Watershed (LCW, Figure 2) located on the eastern slope of the Sierra Nevada Mountains in California. The ARS overlies a shallow unconfined aquifer that is composed primarily of fine to medium sand with varying amounts of silt and clay, and hydraulically connected to the Cimarron River [Butler et al., 2005]. The major phreatophytes at the site are salt cedar (Tamarix spp.) with minor amounts of Russian olive (Elaeagnus angustifolia), a mix that is representative of many arid and semiarid watersheds in the United States where invasive species dominate native vegetation [Zavaleta, 2000; Shafroth et al., 2005; Glenn and Nagler, 2005]. The DT overlies a series of interbedded clays, silts, and sands that are in 


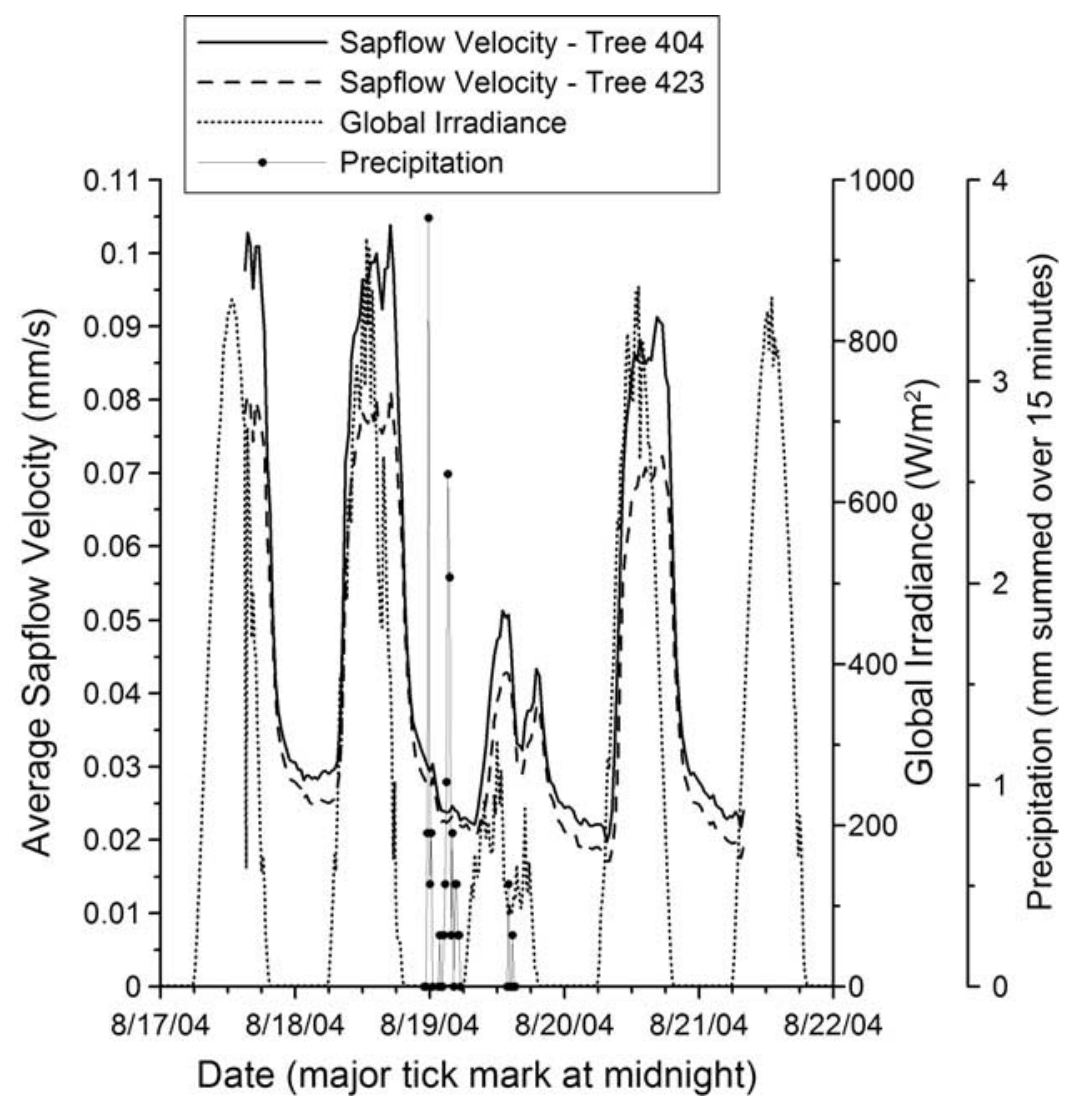

Figure 3a. Average sap flow velocity measured in two cottonwoods in LRS with global irradiance and precipitation measured at LRS weather station. $\mathrm{ET}_{0}$ was $5.5,6.3,1.5,4.1$, and $4.8 \mathrm{~mm} / \mathrm{d}$ for 17-21 August, respectively. Daily total rainfall was 0, 4.6, 11.4, 0, and $0 \mathrm{~mm}$ for 17-21 August, respectively. Sap flow velocity measurements were obtained every $30 \mathrm{~min}$; average is over three sensors equally spaced around the circumference of the tree. Measured circumference at chest height was $0.66 \mathrm{~m}$ and $0.99 \mathrm{~m}$ for trees 404 and 423 , respectively. Note the two major peaks in global irradiance on 19 August and the corresponding but lagged in time peaks in sap flow velocity. In general, the lag between the increase in global irradiance in the morning and the onset of plant water uptake is much shorter than that between the evening decreases in global irradiance and plant water uptake.

hydraulic connection with the South Fork of the Solomon River [Butler et al., 2002]. The riparian zone vegetation is similar to that found at the LRS [Kansas Department of Agriculture, 2004]. The LCW consists of meadows that are in various stages of rehabilitation. The shallow subsurface at the site is composed primarily of silt-rich deposits that are in hydraulic connection with nearby streams. The vegetation depends on the degree of meadow degradation, but primarily consists of sedges (Carex spp.), rushes (Juncus spp.), grasses (Poaceae spp.), and other herbaceous species near the wells considered here. The monitoring wells at all three auxiliary sites are equipped with sensors similar to those used at the LRS.

\section{Major Controls on Diurnal Fluctuations}

\subsection{Temporal Variations in Plant Water Use}

[6] Plant water use varies within and between days, as well as within and between seasons. On the timescale of a single day, a primary control on plant water use is global irradiance, which is negligible at night but increases rapidly after sunrise on a cloud-free day, reaches a peak around midday, and then falls rapidly as sunset approaches. The similarity between the pattern of global irradiance and that of water movement in cottonwoods at the LRS is striking. For example, the sizable reduction in global irradiance on 19 August 2004 as a result of overcast skies and associated precipitation is accompanied by a large decrease in plant water uptake (Figure 3a). Although many studies have shown that such variations in global irradiance and sap flow velocity are highly correlated, global irradiance is not the sole meteorological driver of plant water use. Vapor pressure deficit, air temperature, and wind speed also play critically important roles [Campbell and Norman, 1998]. In this work, we will consider the combined impact of these quantities using the reference evapotranspiration parameter $\left(\mathrm{ET}_{0}\right.$ [Allen et al., 1998]) to characterize the potential for transpiration by riparian zone vegetation when water is not a limiting factor.

[7] The relationship between variations in plant water uptake and water table fluctuations can be readily established by examining multiday suites of meteorological, water table, and sap flow data (Figure 3b). The large reduction in plant water uptake on 19 August 2004 diminished the diurnal fluctuations in the water table to an almost imperceptible level. Although subtle changes in slope on the 


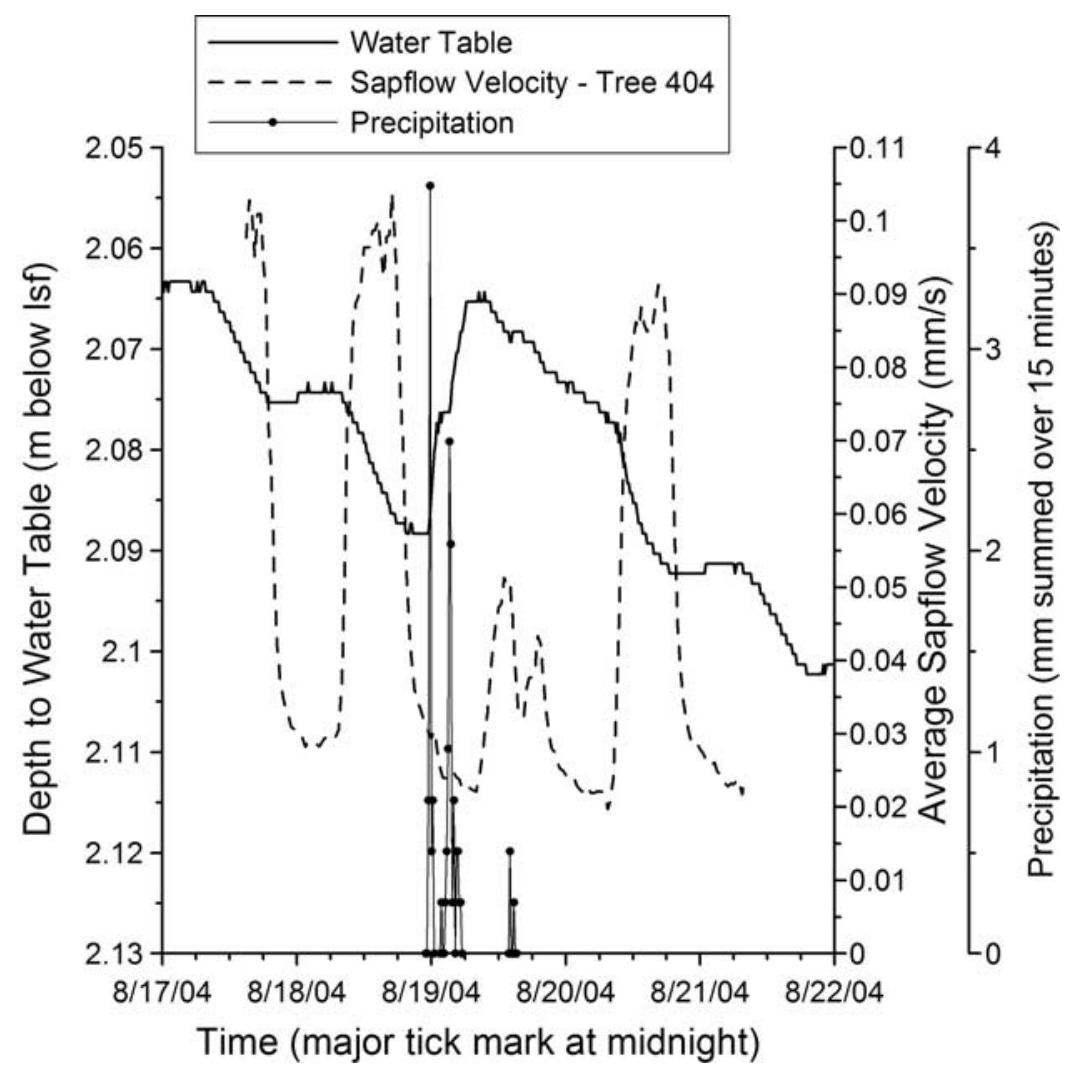

Figure 3b. Depth to water table from land surface at well LWPH2 in LRS with sap flow velocity and precipitation as in Figure $3 a$ (well located in the center of the riparian zone just west of the river channel (Figure 2)). There was no flow in the Arkansas River at the LRS during this period. The general decline in the water table is caused by plant water use and by pumping in the underlying High Plains aquifer.

water table plot during the daylight hours of 19 August may be related to the peaks and troughs in the sap flow plot, the decrease in the elevation of the water table from the afternoon of 19 August to the early morning of 20 August is primarily a response to the redistribution of recharge associated with the $16 \mathrm{~mm}$ of precipitation that fell during the night of 18-19 August and the afternoon of 19 August. Diurnal fluctuations in the water table only become clearly discernible again after a strong diurnal variation in plant water uptake is reestablished on 20 August. The lag between the commencement of plant water uptake and the change in slope of the water table plot on Figure $3 \mathrm{~b}$ for 18 and 20 August is between one and two hours, an indication of the tight coupling between plant water use and the water table response. Bond et al. [2002] found considerably longer (4-8 hours) lags in an investigation of the relationship between plant water uptake and diurnal variations in stream discharge in a small experimental watershed. Such longer lags for variations in stream discharge are expected because of the time required for ground water to flow to the stream [see Bond et al., 2002, Figure 1]. As will be shown in a following section, the response of the water table to temporal variations in plant water uptake does depend on the source of the water being utilized by the plants. When the vadose zone is a significant source of water for riparian vegetation, water table fluctuations will be greatly diminished [Loheide et al., 2005].
[8] Often, on the timescale of a few days to a week, the major control on plant water use is variations in the meteorological quantities that determine conditions for evapotranspiration (i.e., global irradiance, vapor pressure deficit, wind speed, and air temperature). Over the seasonal timescale, however, two of these quantities, global irradiance and temperature, dominate at the LRS. Figure 4 displays 5-day records from a typical well in the LRS for three periods from midspring to midsummer 2003. In mid-April of 2003, the trees had not leafed out and diurnal fluctuations are not discernible in the water level data. The diurnal pattern of water table variations became discernible in May and the amplitude of the variations gradually increased into July. This progressive increase in the amplitude of the variations with time was most likely produced by an increase in $\mathrm{ET}_{0}$ coupled with a gradual depletion of vadose zone moisture and an increasing dependence on ground water [e.g., Engel et al., 2005; Naumburg et al., 2005]. In the fall, the variations disappeared gradually as lower temperatures and the shorter photoperiod induced the plants to transition into dormancy for winter. Data from the DT auxiliary site illustrate the nature of water level responses during this transition period. In the case of a relatively early killing frost, fluctuations terminate abruptly and, often, there is a sudden change in the multiday trend in the water table elevation (Figure 5). A gradual transition into dormancy is accompanied by a progressive diminishing in diurnal fluctuations and, commonly, a gradual change in 


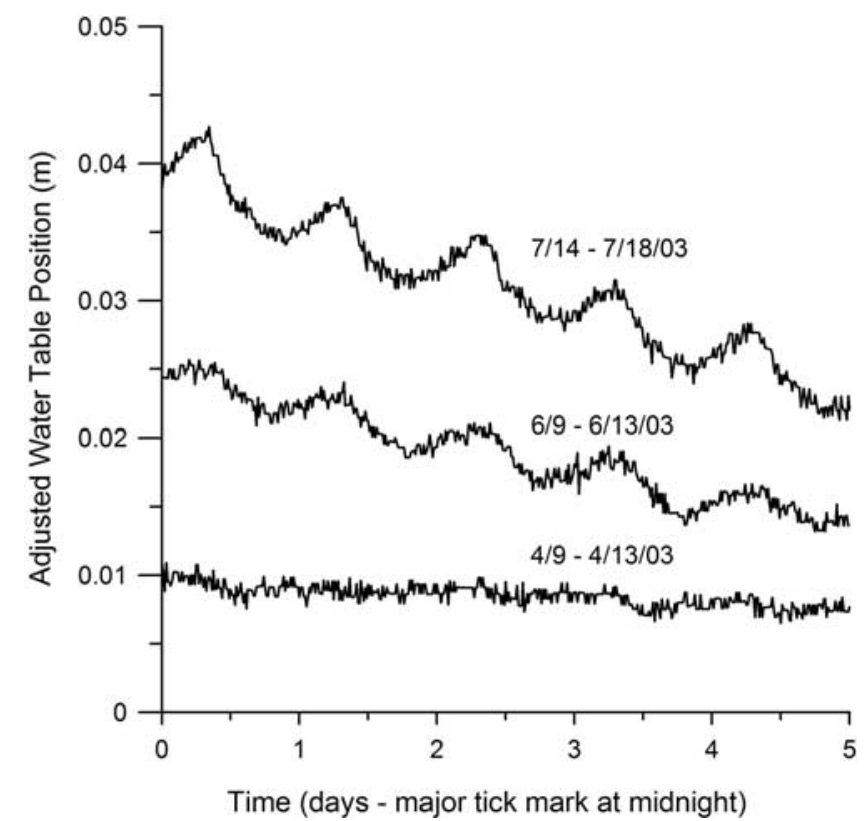

Figure 4. Seasonal variations in water table fluctuations at well LWPH3 in LRS. Depth to water table from land surface was within $0.05 \mathrm{~m}$ of $2.1 \mathrm{~m}$ for all three periods. Water table position was adjusted to enhance clarity by subtracting a different constant value from each 5-day record. Average $\mathrm{ET}_{0}$ was $4.6 \mathrm{~mm} / \mathrm{d}$ and $9.3 \mathrm{~mm} / \mathrm{d}$ for 10-13 June (no 9 June $2003 \mathrm{ET}_{0}$ estimate) and 14-18 July, respectively. Major phreatophytes at LRS had not leafed out by 9-13 April period. The break in multiday trend in final day of 913 June data coincides with a reduction in $\mathrm{ET}_{0}$ to $2.9 \mathrm{~mm} / \mathrm{d}$. The well is located in a clearing midway between the river channel and the western edge of the riparian zone (Figure 2). There was no flow in the Arkansas River and no precipitation at the LRS during these periods; the general decline in the water table during the latter two periods is caused by plant water use and by pumping in the underlying High Plains aquifer.

the multiday trend (data not shown). The timing and nature of the transition into dormancy can vary greatly between years depending on a variety of factors including available water and the meteorological conditions earlier in the season. Analogous dormancy-induced changes have frequently been reported in the flow and stage of base-flowfed streams [e.g., Goodrich et al., 2000; Lundquist and Cayan, 2002].

\subsection{Spatial Variations in Vegetation}

[9] Characteristics of phreatophytic vegetation vary across the riparian zone, and groundwater consumption per unit area of the riparian zone varies accordingly. Data collected at the LRS in midsummer of 2003 demonstrate that the amplitudes of the diurnal water table fluctuations depend on vegetation density, type, and size (Figure 6). Well LWPH2 is in an area with a relatively high density of mature cottonwood trees, whereas LWPH6 is in an area with a relatively high density of smaller trees, mostly mulberries, and no cottonwoods. Well LEA1 is in an area of lowerdensity vegetation but the existing cottonwoods are the largest in the LRS and are considerably older than trees in the low-lying areas to the west of the river channel. Well LWPH3 is located in a clearing on the west side of the river channel that is surrounded by a mix of mature cottonwoods and smaller trees. Depth to the water table does not appear to be a limiting factor in the responses displayed in Figure 6, as the water table is over a meter deeper at LEA1 than at well LWPH3 but the amplitudes of the diurnal fluctuations are essentially the same.

[10] The vitality of the phreatophytic vegetation often varies across the riparian zone, and, consequently, can result in spatial variations in groundwater consumption. Figures 1 and 7 depict variations in water table position for the same time period at two wells in the ARS auxiliary site. The wells are less than $100 \mathrm{~m}$ apart with well Ash32 being closer to the river. Although the salt cedar in the vicinity of both wells was last cut in the fall of 1996, the size and vitality of the vegetation is dramatically different. The visually apparent differences in the vitality of the vegetation are accompanied by large differences in the amplitudes of the diurnal water table fluctuations observed at the two wells. The explanation for these differences has yet to be determined but is likely related to differences in underlying soil conditions (average sand, silt, and clay percentages from

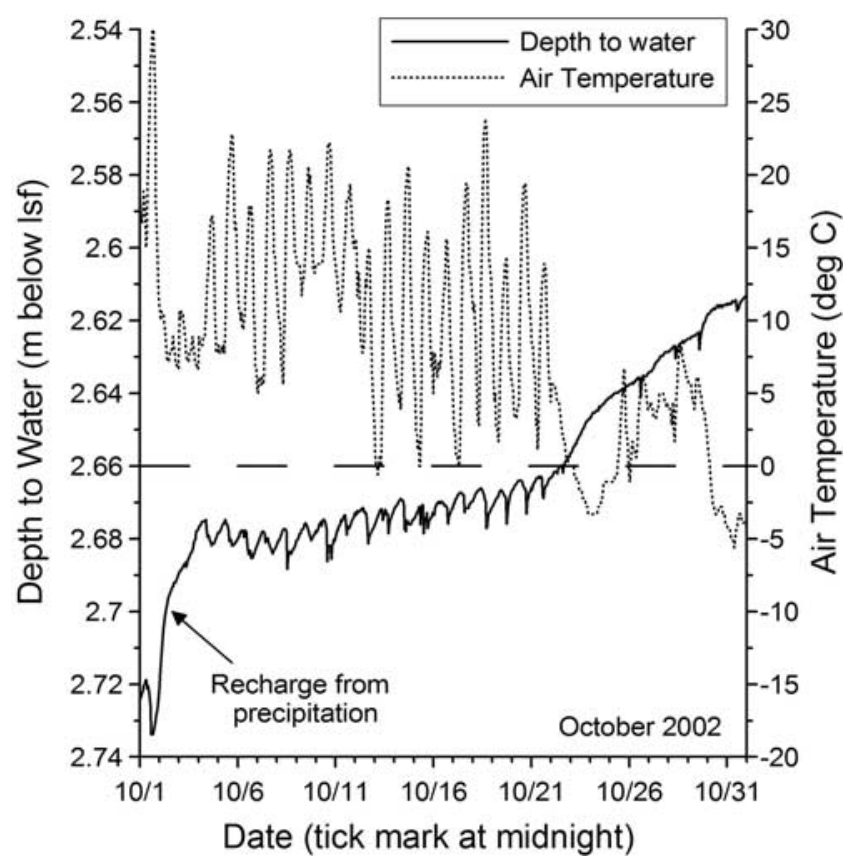

Figure 5. Depth to water from land surface at well RO20 in DT and air temperature for October of 2002. Water level measurements were taken every $15 \mathrm{~min}$; air temperature was measured hourly at Hill City (Kansas) Municipal Airport approximately $21 \mathrm{~km}$ from DT. A small well for livestock is located within $30 \mathrm{~m}$ of $\mathrm{RO} 20$; the pump in the well is activated by float in stock tank; cattle were in pasture with well during this period, and water use by the cattle periodically caused pump operation and thus the downward spikes that are observed in the water level record on most days from 8-22 October and periodically thereafter. There was no flow in the South Fork of the Solomon River during this time and no precipitation beyond the marked event. 


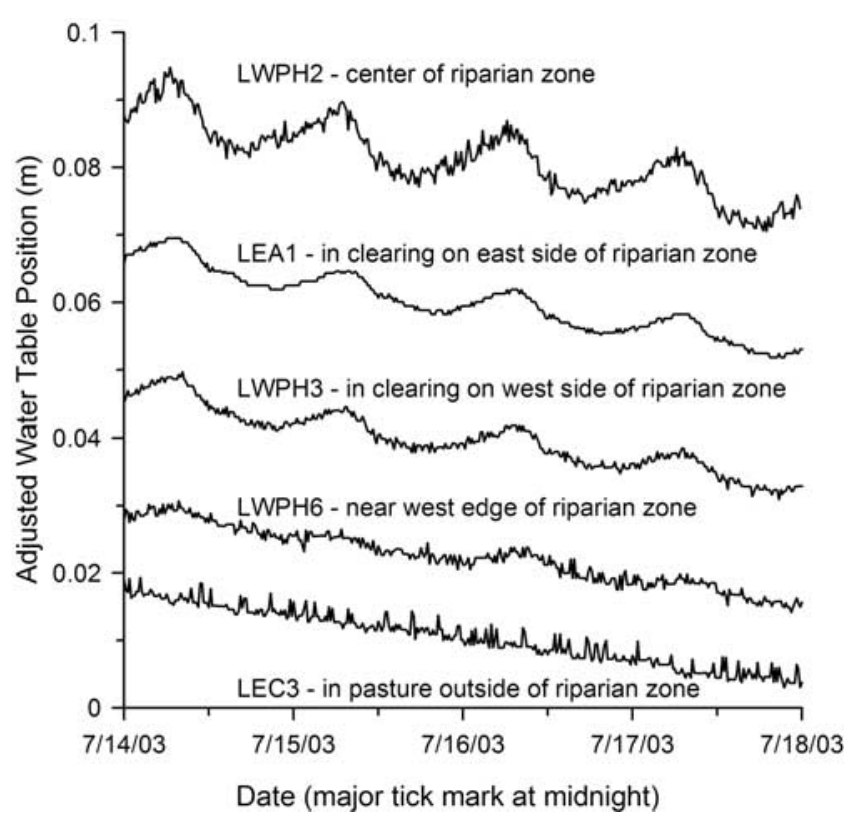

Figure 6. Variations in water table position within and near the LRS riparian zone in mid-July of 2003. Average depth to water from land surface during this period was $2.34 \mathrm{~m}, 2.13 \mathrm{~m}, 2.25 \mathrm{~m}, 3.19 \mathrm{~m}$, and $3.36 \mathrm{~m}$ for wells LWPH2, LWPH3, LWPH6, LEA1, and LEC3, respectively. Water table position was adjusted to enhance plot clarity by subtracting a different constant value from each well record. Wells are arranged in order of distance from center of riparian zone; see Figure 2 for well locations. Average $\mathrm{ET}_{0}$ for period was $9.3 \mathrm{~mm} / \mathrm{d}$. There was no flow in the Arkansas River and no precipitation at the LRS during this period. The general decline in the water table is caused by plant water use and by pumping in the underlying High Plains aquifer. Specific yield was found to be $0.19-0.21$ for most intervals in the sand and gravel aquifer underlying the LRS riparian zone [McKay et al., 2004].

continuous core samples taken over the upper $1.067 \mathrm{~m}$ (42 inches) in the vicinity of both wells are 52.6, 32.1, and 15.3, respectively, for $\mathrm{Ash} 22$, and 87.3, 11.0, and 1.7, respectively, for Ash32). Diurnal fluctuations are almost imperceptible at well Ash32, indicating that the vegetation in the vicinity of that well, salt cedar, forbs, and grasses, is using little ground water despite the proximity of the water table to the land surface.

[11] One factor contributing to differences in groundwater consumption within and between sites is the depth of the root network. Data from the LCW auxiliary site illustrate the impact of root depth on diurnal fluctuations in the water table (Figure 8). At the Alkali Flat well, diurnal fluctuations significantly diminish as the water table falls past the zone of maximum root depth for vegetation in the recently rehabilitated meadow in the vicinity of that well. Data from wells within more established riparian communities at the LCW (e.g., Doyle Crossing) show that diurnal fluctuations continue to be observed beyond the depth range of Figure 8, indicating that the root network associated with the more established vegetation can access the ground water at those greater depths. The relationship of root depth to past hydrologic conditions is explored more fully in the following section.

\subsection{Temporal and Spatial Variations in Hydrologic Conditions}

[12] Data from the LRS reveal the importance of the past hydrologic conditions experienced by riparian zone vegetation. Figure 9 shows plots of the depth to water at well LWPH3 for the same 5-day interval in late spring of 2003 and 2004. Diurnal fluctuations are imperceptible in the water level data from June 2004, despite the nearly $50 \%$ larger $\mathrm{ET}_{0}$ (i.e., higher potential for ET). The most likely explanation for the absence of fluctuations in the 2004 data is that the water table, which is $0.32 \mathrm{~m}$ deeper than in June 2003 , is out of reach, at least temporarily, of the root network of the riparian zone vegetation [Shafroth et al., 2000]. Sap flow data collected during these two periods from cottonwoods of similar size and apparent vitality support this explanation, as the 2004 sap flow velocities are greatly reduced relative to those of 2003 (maximum sap flow velocity reduced by a factor of 5.9). Neutron log data from 2004 are consistent with the sap flow data, as volumetric water content is near the permanent wilting point over most of the vadose zone. Field notes from a site visit on 4 June 2004 (J. Butler, unpublished notes, 2004) report yellow leaves on and premature leaf fall from many of the cottonwoods in the riparian zone, indicating that the trees were undergoing stress [e.g., Rood et al. 2000]. The water table was near a historical low in early June 2004, so the likely explanation for the stress is that the phreatophytes

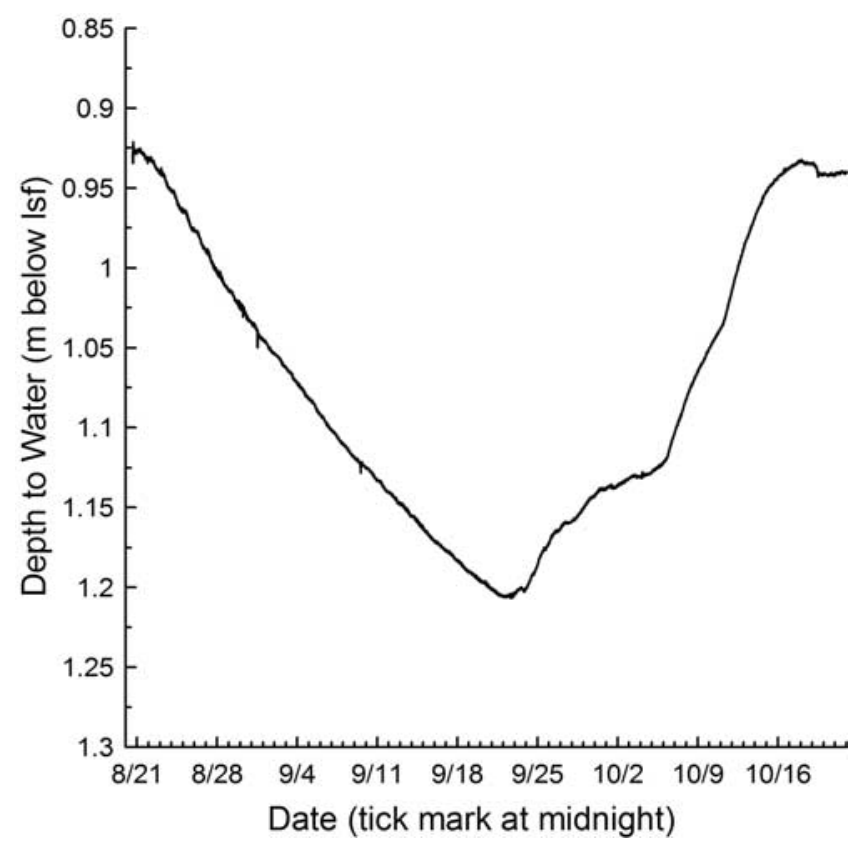

Figure 7. Depth to water from land surface recorded at well Ash32 in the ARS from 20 August to 22 October 2004. Well is located in stand of small salt cedar apparently under stress (many of the salt cedar had a yellowish tinge). Butler et al. [2005] provide details of well site and a photograph of vegetation (salt cedar in the vicinity of well were last cut at the same time as those in Figure 1; see Figure 1 caption for further details regarding post 21 September increases in water level). 


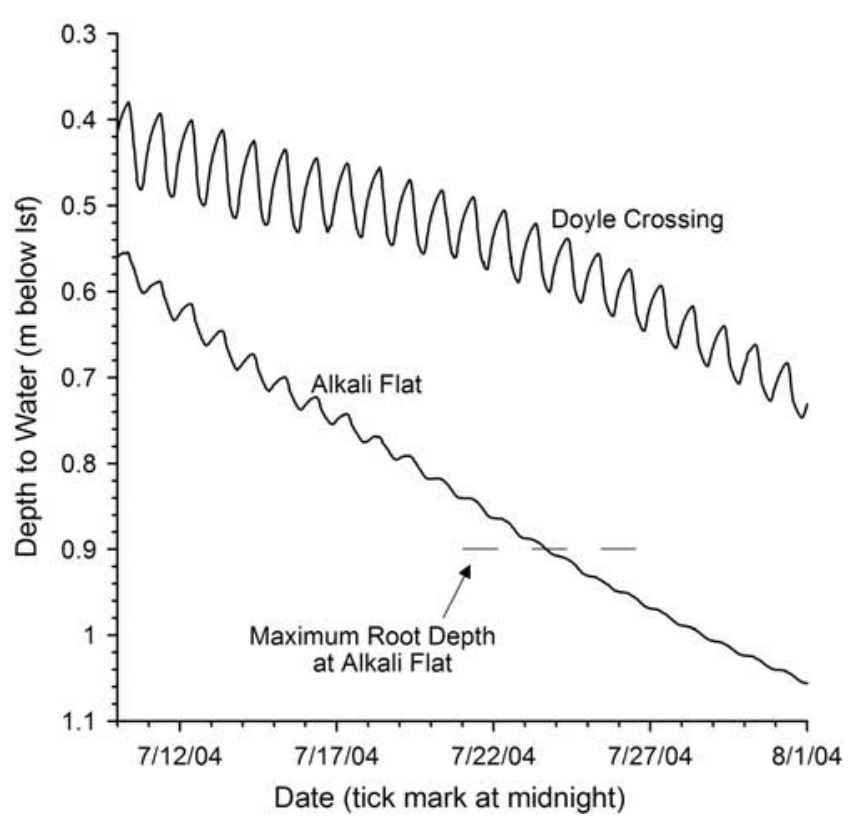

Figure 8. Depth to the water table from land surface recorded at two wells in the LCW. Root distribution at Alkali Flat was determined from measurements on cut banks and in auger holes. Almost all roots were in the top $0.9 \mathrm{~m}$, but tiny root hairs were observed to a depth of $1.3 \mathrm{~m}$. Data from nearby Doyle Crossing well were included to demonstrate that diminishing diurnal fluctuations at the Alkali Flat well were not produced by changing meteorological conditions or senescence of meadow vegetation.

had not had a previous opportunity to develop a root network to extract water from that depth [e.g., Scott et al., 2000; Shafroth et al., 2000]. Phreatophytes at the LRS do have the capability of drawing water from greater depths as illustrated by well LEA1 (Figure 6) located on higher ground (1.05 $\mathrm{m}$ above well LWPH3) on the east side of the riparian zone. However, the trees must have previously developed a root network to extract water from those depths (the water table was also out of reach of vegetation in the vicinity of well LEA1 in early June 2004, but the depth to water from land surface was over a meter greater than at LWPH3). Otherwise, it does not appear that the riparian zone vegetation at the LRS can adapt quickly enough during the growing season to keep pace with a falling water table induced by regional pumping [e.g., Scott et al., 1999; Amlin and Rood, 2003].

[13] Data from the LRS can also be used to observe how riparian zone vegetation responds to hydrologic conditions earlier within the same growing season. Shortly after the June 2004 period shown in Figure 9, the water table rose dramatically $(>2 \mathrm{~m})$ in response to a series of recharge events produced by local precipitation and flow in the Arkansas River. By early September, the water table had fallen back to approximately the same position as in early June 2003 (Figure 10a). The amplitude of the diurnal fluctuations was greater in September 2004, consistent with the $46 \%$ higher $\mathrm{ET}_{0}$. Sap flow velocities, however, were somewhat greater in June 2003 (Figure 10b). The differences in diurnal fluctuations can only be consistent with the sap flow data if the trees were utilizing sizable amounts of moisture from the vadose zone to meet their water needs in June 2003 but not in September 2004. Neutron log data support this interpretation, as the volumetric moisture contents were near field capacity and the permanent wilting point during the June 2003 and September 2004 periods, respectively. Although the lack of vadose zone moisture is a likely reason for the somewhat lower sap flow velocities for the higher $\mathrm{ET}_{0}$ conditions in September 2004, another likely reason is the reduced cottonwood leaf area resulting from the premature leaf fall produced by water stress in June 2004 [e.g., Amlin and Rood, 2003]. Thus the influence of previous hydrologic conditions can be due to both longterm conditions (e.g., root network not developed to extract water below a certain depth), as well as conditions earlier within the same growing season. As shown in this last example, the impact of previous hydrologic conditions within the same growing season can be manifested by decreased groundwater consumption resulting from earlier water stress (e.g., decreased number of leaves) or earlier water excess (e.g., vadose zone moisture is easily obtainable so less dependence on ground water).

[14] Data collected as part of this project, as well as previous field and simulation studies [White, 1932; Rosenberry and Winter, 1997; Laczniak et al., 1999; Loheide et al., 2005], indicate that the magnitude of diurnal water table fluctuations can vary substantially between sites, and even between wells at the same site. A portion of this difference could be attributed to variations in plant water uptake per unit area of riparian zone (e.g., Figure 6). Often, however, an equally if

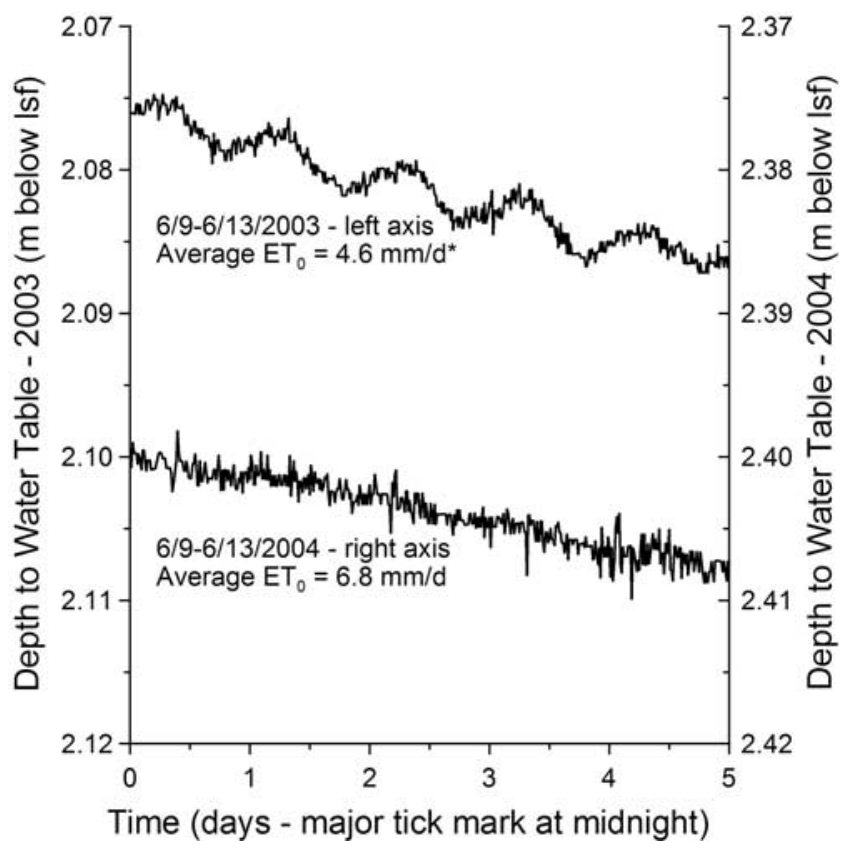

Figure 9. Variations in water table position at well LWPH3 in the LRS for early June of 2003 and 2004. Asterisk indicates no 9 June $2003 \mathrm{ET}_{0}$ estimate; break in trend in final day of 2003 data coincides with a reduction in $\mathrm{ET}_{0}$ to $2.9 \mathrm{~mm} / \mathrm{d}$. There was no flow in the Arkansas River and little precipitation $(0.002 \mathrm{~m}$ on 9 June 2004) at the LRS during these periods. The general decline in the water table is caused by plant water use and by pumping in the underlying High Plains aquifer. 


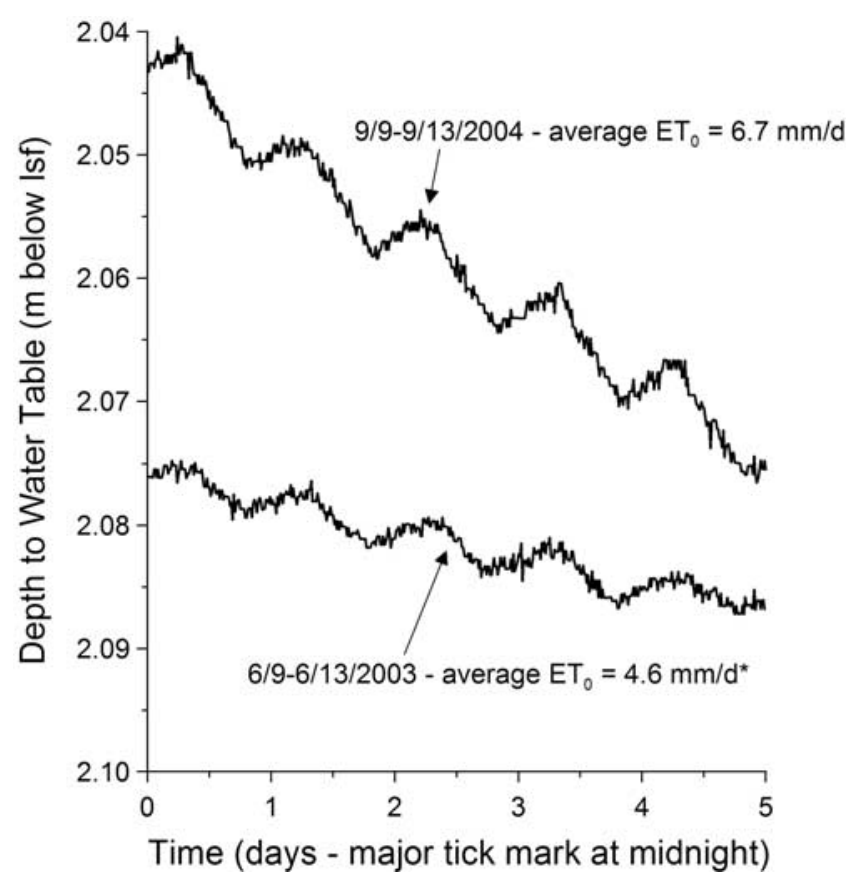

Figure 10a. Depth to water from land surface at well LWPH3 in the LRS for periods of approximately equal water table position in June 2003 and September 2004. Asterisk indicates no 9 June $2003 \mathrm{ET}_{0}$ estimate; break in trend in final day of 2003 data coincides with a reduction in $\mathrm{ET}_{0}$ to $2.9 \mathrm{~mm} / \mathrm{d}$. There was no flow in the Arkansas River and no precipitation at the LRS during these periods. The general decline in the water table is caused by plant water use and by pumping in the underlying High Plains aquifer.

not more important factor is variations in the specific yield of sediments in the vicinity of the water table. As an example of this point, Figure 11 displays data from wells in the LRS and the LCW auxiliary site. Although the $\mathrm{ET}_{0}$ is greater at the LRS, the amplitude of fluctuations in the LCW well is close to an order of magnitude larger. At the LRS, the water table is over two meters below land surface and the highly permeable sediments drain rapidly relative to the timescale of the diurnal fluctuations. The standard definition of specific yield (total drainable porosity) should therefore be appropriate. McKay et al. [2004] used this definition and the method of Skaggs et al. [1978] to estimate a specific yield of $0.19-0.21$ for most intervals in the sand and gravel aquifer at the LRS. In contrast, in the vicinity of the LCW well, the water table is close to the land surface and the predominantly silty sediments drain relatively slowly. The concept of the readily available specific yield must therefore be invoked to account for the fact that the shallow depth to water reduces the amount of water released per unit drop in the water table and that the water is not released instantaneously in response to the drop [Meyboom, 1967; Healy and Cook, 2002; Loheide et al., 2005]. The simulation approach of Loheide et al. [2005] was used to estimate a specific yield of $0.02-0.03$ for silty sediment in the vicinity of the LCW well. The nearly one order of magnitude difference in specific yield between the two sites is consistent with the shallow sediments predominating at each site and the nearly order of magnitude difference in the amplitude of the diurnal fluctuations. Thus a reasonable estimate of specific yield for the sediments in the vicinity of the water table must be available to fully understand the implications of the magnitude of the diurnal water table fluctuations (see Figure 10 of Loheide et al. [2005] for textural-based specific yield estimates).

\section{Estimation of Groundwater Consumption by Phreatophytes}

[15] Groundwater consumption by phreatophytes is commonly a highly uncertain component of the hydrologic budget of a stream-aquifer system [e.g., Goodrich et al., 2000; Loheide et al., 2005]. As shown in the previous sections, water table records from shallow wells in vegetated riparian zones provide valuable information about groundwater use by plants and therefore could potentially help reduce the uncertainty regarding this component of the hydrologic budget. The critical issue, however, is how to extract the relevant information from the water table records. One such approach is described and demonstrated in this section.

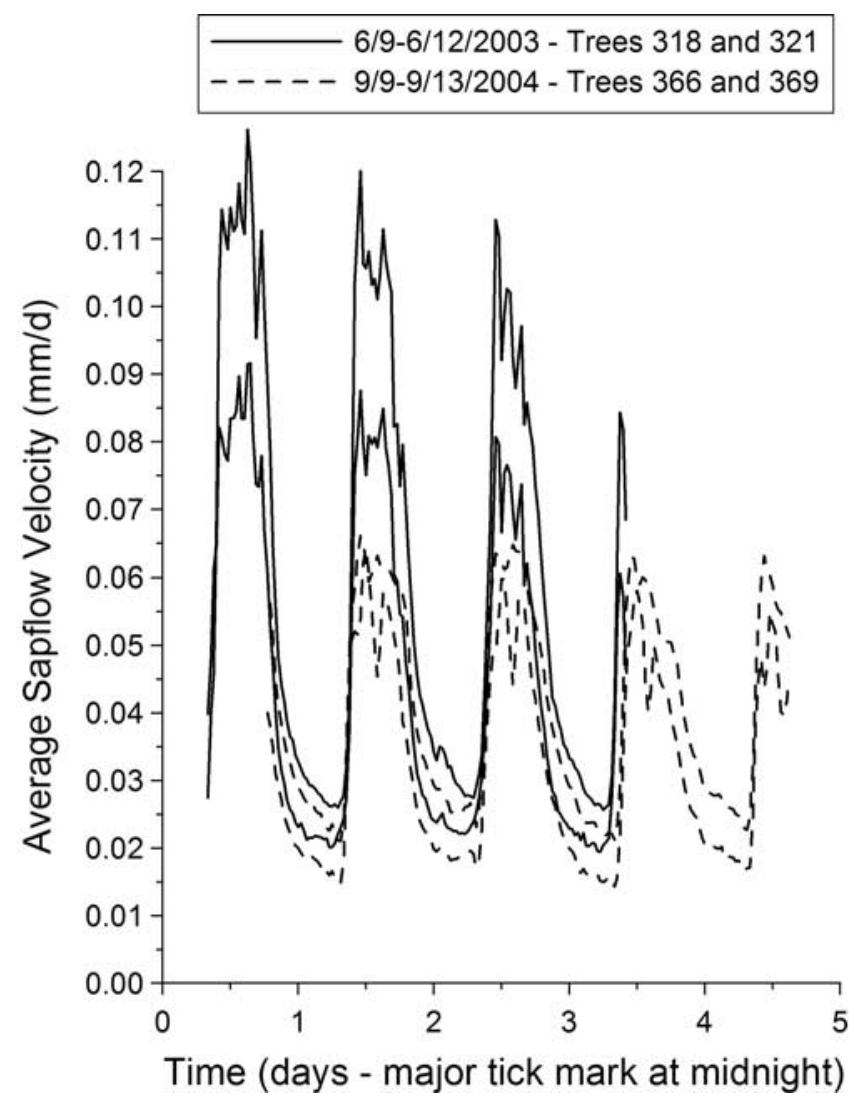

Figure 10b. Variations in average sap flow velocity from cottonwood trees located near the center of the LRS riparian zone for early June 2003 and early September 2004. See Figure $3 \mathrm{a}$ for details concerning sap flow velocity measurements. The measured trunk circumference at chest height was $0.89 \mathrm{~m}, 0.92 \mathrm{~m}, 0.58 \mathrm{~m}$, and $1.25 \mathrm{~m}$ for trees $318,321,366$, and 369, respectively. The trees appeared to be of similar vitality. 


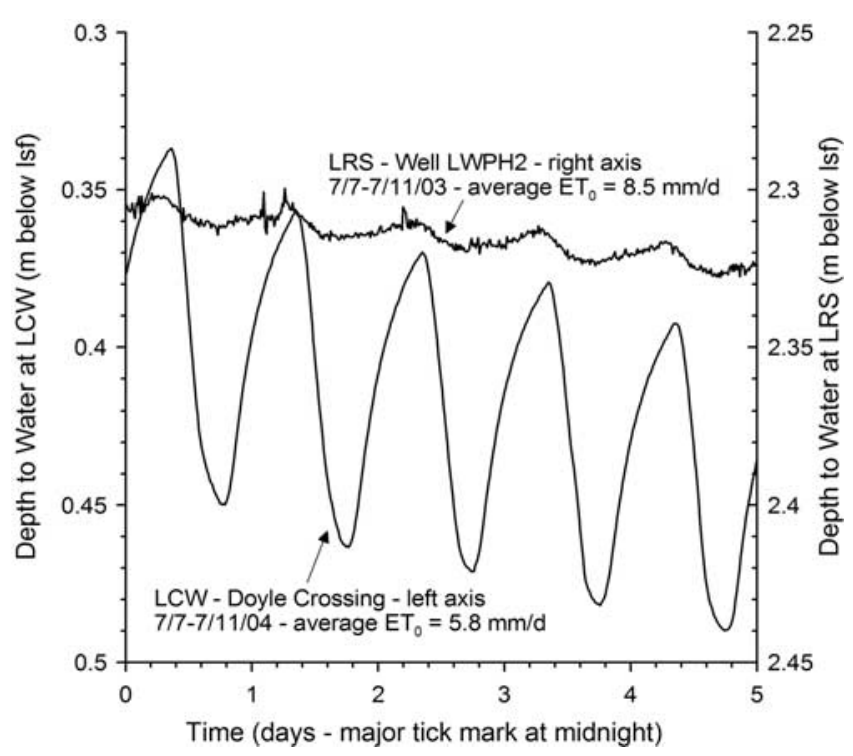

Figure 11. Variations in diurnal fluctuations in the water table between wells at the LRS and LCW. Shallow subsurface is primarily coarse sand and gravel at LRS, whereas it is primarily silt at LCW. LRS 7-11 July 2004 data were impacted by high river flows and so are not presented. LCW was not monitored in 2003. Diurnal fluctuations at well LWPH2 have the largest amplitude observed in the vegetated riparian zone at the LRS.

[16] White [1932] proposed an empirical method for estimation of groundwater consumption by phreatophytes using hydrographs from wells screened across the water table and the expression (Figure 12):

$$
\mathrm{ET}_{G}=S_{Y}(r \pm s)
$$

where $\mathrm{ET}_{G}$ is the evapotranspirative consumption of ground water expressed as a daily rate, $S_{Y}$ is the readily available specific yield (dimensionless), $r$ is the net inflow calculated from the nighttime recovery expressed as a daily rate, and $s$ is the net change in water table position over one day expressed as a daily rate (by convention positive with decrease in water table elevation). The net inflow term $(r)$ is the average of the net inflows calculated for the two nights bounding the day in question [Loheide et al., 2005].

[17] Loheide et al. [2005] performed a series of numerical simulations to assess the ramifications of the assumptions underlying the White method and the viability of the resulting $\mathrm{ET}_{G}$ estimate. They found that the White method provides reasonable estimates (within 20\%) for formations consisting primarily of sands and gravels when the specific yield is defined as the total drainable porosity. However, in finer-grained materials, an estimate of the readily available specific yield, a more difficult to determine quantity, must be utilized to obtain reasonable $\mathrm{ET}_{G}$ estimates.

[18] The shallow subsurface at the LRS consists primarily of sand and gravel so the White method should provide reasonable $\mathrm{ET}_{G}$ estimates, particularly given that in situ $S_{Y}$ estimates are available for the site [McKay et al., 2004]. Data from well LWPH3 can be used for a simple demonstration of the methodology as the fluctuations at that well appear to be representative of average fluctuations across the riparian zone (Figure 6 and other data not shown). An average $\mathrm{ET}_{G}$ of $4.2 \mathrm{~mm} / \mathrm{d}$ was obtained for the 2628 August 2002 period using the LWPH3 water level data (Figure 12) and a $S_{Y}$ value of 0.20 [McKay et al., 2004]. Assuming a riparian zone width of $150 \mathrm{~m}$ (a reasonable average for the Arkansas River in the area (Figure 2)), this $\mathrm{ET}_{G}$ value results in an average daily groundwater consumption of $0.62 \mathrm{~m}^{3} / \mathrm{d}$ for a meter-wide strip extending the full width of the riparian zone. This average daily groundwater consumption per meter of river channel equates to a high-capacity pumping well (defined for the vicinity of the LRS as a well pumping continuously at $3.3 \times 10^{3} \mathrm{~m}^{3} / \mathrm{d}$ (600 gallons/min)) located every $5.3 \mathrm{~km}$ along the river channel. This equivalence should be considered valid only for conditions near the maximum rate of groundwater consumption at the LRS, as the water table was relatively shallow during this period and the amplitude of the fluctuations was relatively large (compare Figures 4, 6, 9, $10 \mathrm{a}$, and 12). A more complete analysis of the water table fluctuations at the LRS is ongoing.

\section{Discussion}

[19] Diurnal water table fluctuations are commonly observed in shallow wells located in vegetated riparian zones. Field data presented here and elsewhere [e.g., White, 1932; Robinson, 1958] demonstrate that these fluctuations are a product of variations in plant water use at most sites. Diurnal water table fluctuations should therefore be considered an important indicator of groundwater consumption by phreatophytes. Use of these fluctuations as such an indicator has largely been ignored in the ecohydrology literature, where depth to the water table has been the primary hydrogeologic quantity of interest (e.g., see review papers

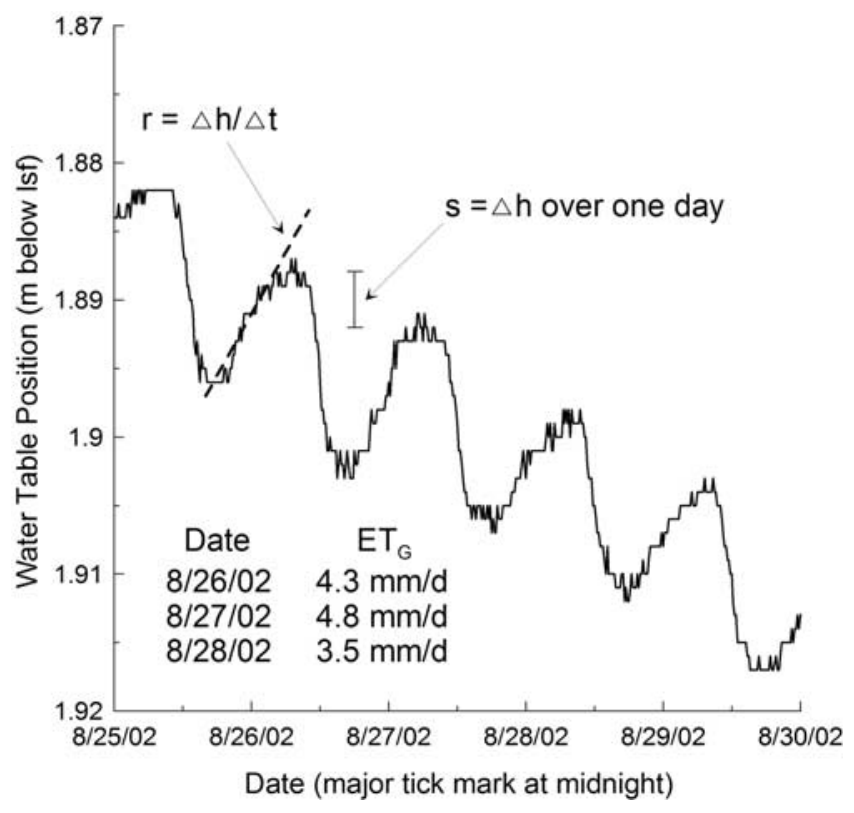

Figure 12. Example application of the White method using late August 2002 water level data from well LWPH3 at the LRS. There was no flow in the Arkansas River and little precipitation ( 0.003 and $0.002 \mathrm{~m}$ for 26 and 27 August, respectively) at the LRS during this period. 
by Le Maitre et al. [1999] and Naumburg et al. [2005] and literature review by Cooper et al. [2006]). Although care must be employed to avoid misinterpreting water table fluctuations induced by other mechanisms, the temporal regularity of plant-induced oscillations (e.g., Figure 1) greatly reduces the possibility for such misinterpretations. However, when the capillary fringe extends to the land surface or just below, direct evaporation from the water table can produce a similar diurnal pattern [White, 1932; Robinson, 1958]. Thus the nature of near-surface sediments and hydrologic conditions cannot be ignored when considering possible mechanisms for the observed fluctuations [e.g., Tyler et al., 2006].

[20] Phreatophyte-induced fluctuations in the water table (or the lack thereof) can provide valuable information about groundwater consumption at a scale that is intermediate between that of individual plants and that of a stand or reach. For example, information about water use based on sap flux measurements from a small number of phreatophytes can be far from representative because of the variability in water use between plants of differing species, age, size, exposure, and vitality. Water table variations, however, are the integrated response to a group of highly heterogeneous and difficult-to-characterize water stresses at the scale of a number of phreatophytes; a more precise definition of that scale is the subject of an ongoing field investigation. This scale of integration is undoubtedly site dependent, as it should be a function of a number of factors including the nature of the root network and the hydraulic properties of the sediments. Under certain conditions, as is discussed below, the water table variations can be coupled with isotopic data to estimate total plant water use. The ramifications for detailed studies of plant water use across the riparian zone are considerable.

[21] Methodology for estimation of evapotranspirative consumption of ground water $\left(\mathrm{ET}_{G}\right)$ using hydrographs from shallow wells is still undergoing refinement. The approach of White [1932] appears to provide reasonable estimates for riparian zones underlain by sands and gravels [Loheide et al., 2005], but its extension to finer-grained materials is more questionable because of the difficulty in obtaining reliable estimates for the readily available specific yield [e.g., Rosenberry and Winter, 1997]. More attention should therefore be given to the development of practical methods for obtaining estimates of readily available specific yield that are appropriate for the timescales of interest in studies of plant water use. In addition, given the potential for vertical variability in sediment properties, it is critical that the specific yield estimate be reflective of the sediments in the vicinity of the water table.

[22] $\mathrm{ET}_{G}$ estimates, such as those obtained with the White method (equation (1) and Figure 12), must be used with caution for reach-scale assessments of total plant water use for two primary reasons. First, the width of the riparian zone can vary significantly within a short distance because of differing land use practices (aerial photo in Figure 2). The composition of the riparian zone vegetation can also change substantially in a short distance for this and other reasons. Such variations will result in variations in $\mathrm{ET}_{G}$ across the riparian zone and along a reach. The viability of an average $\mathrm{ET}_{G}$ estimate based on a small number of wells has yet to be determined. Intensive ecohydrologic studies like that ongo- ing at the LRS should help clarify how $\mathrm{ET}_{G}$ varies within the riparian zone and provide insight into well placement. Second, and most importantly, methods based on water table fluctuations will only provide estimates of the groundwater component of plant water use; total plant water use may be much larger. Reach-scale estimates of total plant water use can be difficult to obtain for narrow riparian corridors, such as that at the LRS and elsewhere in the High Plains region of the United States. Although energy balance or eddy correlation methods are widely used approaches for determining ET [Shuttleworth, 1993; Dahm et al., 2002], their fetch requirements are often too large for narrow riparian corridors [Goodrich et al., 2000]. One promising approach is the combination of a method for estimation of $\mathrm{ET}_{G}$ with isotopic analysis of plant water. Isotopic tracers [Dawson and Ehleringer, 1991; Brunel et al., 1995; Chimner and Cooper, 2004] are proven tools for determination of the fraction of transpired water contributed by ground water when that water can be isotopically differentiated from other sources. Thus, given the fraction of transpired water originating as ground water and an $\mathrm{ET}_{G}$ estimate, a reasonable estimate of total plant water use should be possible. This approach holds out the promise that reach-scale estimates of plant water use could be based on remotely sensed riparian zone widths and vegetation composition, a few strategically placed wells along a representative reach, and isotopic analyses of water samples from the subsurface (saturated and vadose zones) and major phreatophytes. The feasibility of such an approach is the subject of ongoing work.

[23] Acknowledgments. This material is based upon work supported in part by the Kansas Water Resources Institute under grant 01HQGR0081 (subaward S04015), a joint agreement between the Kansas Geological Survey and Big Bend Groundwater Management District 5, the Kansas Water Office under contract 05-114, and the National Science Foundation under grant EAR-0337393 (support of Stanford activities at Last Chance Watershed). Any opinions, findings, and conclusions or recommendations expressed in this material are those of the authors and do not necessarily reflect the views of the Kansas Water Resources Institute, Big Bend Groundwater Management District 5, the Kansas Water Office, or the National Science Foundation. Field support provided by J. Healey, J. Heitman, K. Baum, R. Newman, M. Buckley Zeimen, J. Uribe, G. Davis, S. Cain, R. Brauchler, S. McKay, M. Aufman, and C. Barden is gratefully acknowledged. Land access granted by A. D. Apley, D. Arnold, L. Borck, and the Plumas National Forest was critical for the work reported here and is gratefully acknowledged. This manuscript greatly benefited from comments by three anonymous reviewers.

\section{References}

Allen, R. G., L. S. Pereira, D. Raes, and M. Smith (1998), Crop evapotranspiration-Guidelines for computing crop water requirements, Irrig. Drain. Pap., 56.

Amlin, N. M., and S. B. Rood (2003), Drought stress and recovery of riparian cottonwoods due to water table alteration along Willow Creek, Alberta, Trees, 17, 351-358.

Bond, B. J., J. A. Jones, G. Moore, N. Phillips, D. Post, and J. J. McDonnell (2002), The zone of vegetation influence on baseflow revealed by diel patterns of streamflow and vegetation water use in a headwater basin, Hydrol. Processes, 16, 1671-1677.

Brunel, J. P., G. R. Walker, and A. K. Kennett-Smith (1995), Field validation of isotopic procedures for determining source water used by plants in a semi-arid environment, J. Hydrol., 167, 351-368.

Butler, J. J., Jr., D. O. Whittemore, J. M. Healey, and M. K. Schulmeister (2002), Stream-aquifer interactions on the Solomon River: Construction, geochemical sampling, and slug testing of groundwater observations wells in Rooks County, Kansas and geological logging of existing wells in Rooks, Smith, and Osborne County, Kansas, Kans. Geol. Surv. Open File Rep., 2002-60, 41 pp.

Butler, J. J., Jr., D. O. Whittemore, X. Zhan, and J. M. Healey (2004), Analysis of two pumping tests at the O'Rourke Bridge site on the 
Arkansas River in Pawnee County, Kansas, Kans. Geol. Surv. Open File Rep., 2004-32, 58 pp.

Butler, J. J., Jr., D. O. Whittemore, and G. J. Kluitenberg (2005), Ground water assessment in association with salt cedar control-Report on year one activities, Kans. Geol. Surv. Open File Rep., 2005-19, 28 pp.

Campbell, G. S., and J. M. Norman (1998), An Introduction to Environmental Biophysics, 286 pp., Springer, New York.

Chimner, R. A., and D. J. Cooper (2004), Using stable oxygen isotopes to quantify the water source used for transpiration by native shrubs in the San Luis Valley, Colorado, USA, Plant Soil, 260, 225-236.

Clinton, B. D., J. M. Vose, D. A. Vroblesky, and G. J. Harvey (2004), Determination of the relative uptake of ground vs. surface water by Populus deltoides during phytoremediation, Int. J. Phytorem., 6(3), 239-252.

Cohen, Y., M. Fuchs, and G. C. Green (1981), Improvement of the heat pulse method for determining sap flow in trees, Plant Cell Environ., 4, $391-397$.

Cooper, D. J., J. S. Sanderson, D. I. Stannard, and D. P. Groeneveld (2006), Effects of long-term water table drawdown on evapotranspiration and vegetation in an arid region phreatophyte community, J. Hydrol., $325(1-4), 21-34$.

Dahm, C. N., J. R. Cleverly, J. E. Allred-Coonrod, J. R. Thibault, D. E. McDonnell, and D. J. Gilroy (2002), Evapotranspiration at the land/water interface in a semi-arid drainage basin, Freshwater Biol., 47, 831-843.

Dawson, T. E., and J. R. Ehleringer (1991), Streamside trees that do not use stream water, Nature, 350, 335-337.

Eddy, T. A. (1995), Phreatophyte survey and water-use estimates for nine river systems in Kansas, in Proceedings of the Fourteenth North American Prairie Conference, edited by D. C. Hartnett, pp. 171-173, Kans. State Univ., Manhattan.

Engel, V., E. G. Jobbagy, M. Stieglitz, M. Williams, and R. B. Jackson (2005), Hydrological consequences of eucalyptus afforestation in the Argentine Pampas, Water Resour. Res., 41, W10409, doi:10.1029/ 2004WR003761.

Gatewood, J. S., T. W. Robinson, B. R. Colby, J. D. Hem, and L. C. Halpenny (1950), Use of water by bottom-land vegetation in Lower Safford Valley Arizona, U.S. Geol. Surv. Water Supply Pap., 1103.

Glenn, E. P., and P. L. Nagler (2005), Comparative ecophysiology of Tamarix ramosissima and native trees in western U. S. riparian zones, J. Arid Environ., 61, 419-446.

Goodrich, D. C., et al. (2000), Seasonal estimates of riparian evapotranspiration using remote and in situ measurements, Agric. For. Meteorol., 105, 281-309.

Healy, R. W., and P. G. Cook (2002), Using groundwater levels to estimate recharge, Hydrogeol. J., 10, $91-109$.

Hultine, K. R., D. G. Williams, S. S. O. Burgess, and T. O. Keefer (2003), Contrasting patterns of hydraulic redistribution in three desert phreatophytes, Oecologia, 135, 167-175.

Kansas Department of Agriculture (2002), Preliminary report on the phreatophyte water consumption within the alluvial corridors of the Solomon River Basin, Subbasin Water Resources Management Program report, 9 pp., Topeka, Kansas.

Kansas Department of Agriculture (2004), Solomon River Basin: $2003-$ Field analysis summary, Subbasin Water Resources Management Program report, 42 pp., Topeka, Kansas.

Kluitenberg, G. J., and J. M. Ham (2004), Improved theory for calculating sap flow with the heat pulse method, Agric. For. Meteorol., 126, 161165.

Kruseman, G. P., and N. A. de Ridder (1990), Analysis and evaluation of pumping test data, ILRI Publ. 47, Int. Inst. for Land Reclam. and Impr., Wagenigen, Netherlands.

Laczniak, R. J., G. A. DeMeo, S. R. Reiner, J. L. Smith, and W. E. Nylund (1999), Estimates of ground-water discharge as determined from measurements of evapotranspiration, Ash Meadows Area, Nye County, Nevada, U. S. Geol. Surv. Water Resour. Invest. Rep., 99-4079, 70 pp.

Le Maitre, D. C., D. F. Scott, and C. Colvin (1999), A review of information on interactions between vegetation and groundwater, Water $S A$, 25(2), 137-152.

Loheide, S. P. II, J. J. Butler, Jr., and S. M. Gorelick (2005), Use of diurnal water table fluctuations to estimate groundwater consumption by phreatophytes: A saturated-unsaturated flow assessment, Water Resour. Res., 41, W07030, doi:10.1029/2005WR003942.

Lundquist, J. D., and D. R. Cayan (2002), Seasonal and spatial patterns in diurnal cycles in streamflow in the western United States, J. Hydrometeorol., 3(5), 591-603.

McKay, S. E., G. J. Kluitenberg, J. J. Butler, Jr., X. Zhan, M. S. Aufman, and R. Brauchler (2004), In-situ determination of specific yield using soil moisture and water level changes in the riparian zone of the Arkansas River, Kansas, Eos Trans. $A G U, 85(47)$, Fall Meet. Suppl., Abstract H31D-0425.

Meinzer, O. E. (1927), Plants as indicators of ground water, U. S. Geol. Surv. Water Supply Pap., 577, 95 pp.

Meyboom, P. (1967), Groundwater studies in the Assiniboine River drainage basin-Part II: Hydrologic characteristics of phreatophytic vegetation in south-central Saskatchewan, Geol. Surv. Can. Bull., 139.

National Research Council (2002), Riparian Areas: Functions and Strategies for Management, 428 pp., Natl. Acad. Press, Washington, D. C.

Naumburg, E., R. Mata-Gonzalez, R. G. Hunter, T. McLendon, and D. W. Martin (2005), Phreatophytic vegetation and groundwater fluctuations: A review of current research and application of ecosystem response modeling with an emphasis on Great Basin vegetation, Environ. Manage., 35(6), 726-740.

Robinson, T. W. (1958), Phreatophytes, U. S. Geol. Surv. Water Supply Pap., 1423, 84 pp.

Rood, S. B., S. Patino, K. Coombs, and M. T. Tyree (2000), Branch sacrifice: Cavitation-associated drought adaptation of riparian cottonwoods, Trees, 14, 248-257.

Rosenberry, D. O., and T. C. Winter (1997), Dynamics of water table fluctuations in an upland between two prairie-pothole wetlands in North Dakota, J. Hydrol., 191, 266-289.

Sala, A., E. V. Carey, and R. M. Callaway (2001), Dwarf mistletoe affects whole-tree water relations of Douglas fir and western larch primarily through changes in leaf to sapwood ratios, Oecologia, 126, 42-52.

Schaeffer, S. M., D. G. Williams, and D. C. Goodrich (2000), Transpiration of cottonwood/willow forest estimated from sap flux, Agric. For. Meteorol., 105, 257-270.

Scott, M. L., P. B. Shafroth, and G. T. Auble (1999), Responses of riparian cottonwoods to alluvial water table declines, Environ. Manage., 23(3), $347-358$.

Scott, M. L., G. C. Lines, and G. T. Auble (2000), Channel incision and patterns of cottonwood stress and mortality along the Mojave River, California, J. Arid Environ., 44, 399-414.

Shafroth, P. B., J. Stromberg, and D. Patten (2000), Woody riparian vegetation response to different alluvial water table regimes, West. North Am. Nat., 60, 66-76.

Shafroth, P. B., J. R. Cleverly, T. L. Dudley, J. P. Taylor, C. Van Riper, III, E. P. Weeks, and J. N. Stuart (2005), Control of Tamarix in the western United States: Implications for water salvage, wildlife use, and riparian restoration, Environ. Manage., 35(3), 231-246.

Shuttleworth, W. J. (1993), Evaporation, in Handbook of Hydrology, edited by D. R. Maidment, pp. 4.1-4.53, McGraw-Hill, New York.

Skaggs, R. W., L. G. Wells, and S. R. Ghate (1978), Predicted and measured drainage porosities for field soils, Trans. ASAE, 22, 522-528.

Stephens, D. B. (1996), Vadose Zone Hydrology, 347 pp., Lewis, Boca Raton, Fla.

Tyler, S. W., J. F. Munoz, and W. W. Wood (2006), The response of playa and sabkha hydraulics and mineralogy to climate forcing, Ground Water, 44(3), 329-338.

West, E., and G. Ruark (2004), A long, long time ago..., J. Soil Water Conserv., 59(5), 105A-110A.

White, W. N. (1932), A method of estimating ground-water supplies based on discharge by plants and evaporation from soil-Results of investigations in Escalante Valley, Utah, U. S. Geol. Surv. Water Supply Pap., 659$A, 105$ pp.

Zavaleta, E. (2000), The economic value of controlling an invasive shrub, Ambio, 29(8), 462-467.

M. A. Billinger, Division of Water Resources, Kansas Department of Agriculture, Stockton Field Office, P.O. Box 192, 820 South Walnut, Stockton, KS 67669, USA.

J. J. Butler Jr. and D. O. Whittemore, Kansas Geological Survey, Campus West, University of Kansas, 1930 Constant Avenue, Lawrence, KS 66047, USA. (jbutler@kgs.ku.edu)

W. Jin and G. J. Kluitenberg, Department of Agronomy, Throckmorton Plant Sciences Center, Kansas State University, Manhattan, KS 665065501, USA.

S. P. Loheide II, Department of Civil and Environmental Engineering, University of Wisconsin-Madison, 1269C Engineering Hall, 1415 Engineering Drive, Madison, WI 53706-1691, USA.

X. Zhan, MACTEC Engineering and Consulting, Inc., 600 Grand Avenue, Number 300, Oakland, CA 94610, USA. 